\title{
Attitude of Farmers and Scientists Towards Dissemination of Technologies Through Mobile Message Service (MMS)
}

\author{
N. Shankaraiah and B.K. Narayana Swamy ${ }^{1 *}$ \\ Department of Agricultural Extension \\ UAS, GKVK, Bangalore - 560065 \\ India
}

\begin{abstract}
Mobile phone used for two way communications, helps to disseminate information, improve farmers' knowledge, increase participation and share knowledge with others. The objectives of the study are to know the attitude of farmers and scientists, profile and constraints of farmers and type of agricultural technologies disseminated through MMS network. Research was conducted at Doddaballapur of Bangalore Rural District, Karnataka, India during 2010-11. The respondents were 40 farmers and 40 scientists selected using simple random technique and collected information using questionnaire and schedules. Key findings of the study reported that forty per cent of farmers and forty five per cent of Scientists had favourable attitude towards MMS network. Further, revealed that education, farm size, material possession, economic motivation, innovative proneness, achievement motivation, cosmopoliteness, mass media participation and extension participation had positive and significant relationship with attitude of farmers. Whereas, cropping intensity, irrigation intensity, decision making ability and social participation had positive and significant relationship with attitude of farmers towards MMS network. Agriculture, horticulture, veterinary, weather information were more relevant technologies disseminated through MMS network. The major constraints faced by farmers are lack of practical exposure, difficulty of clarification if any doubt arises; while among the scientists, lack of practical exposure, and lack of locally relevant information. The implication is to find new mechanism to solve this problem. To conclude the concept of MMS network is a new approach. Hence, there is need to motivate farmers for adoption.
\end{abstract}

Keywords: Attitude, constraints, MMS network, mobile phone.

\section{INTRODUCTION}

In recent years, there has been a rapid growth of mobile message service (MMS) network. Further, most of the developing countries of the world have skipped fixed-line infrastructure and leapfrogged directly into mobile technology. Mobile phone is becoming one of the basic necessities now days for all types of rural and urban people. A mobile phone is an Information Communication Technology (ICT) tool used for two-way communication.

The mobile phone has become more useful in the modern days and agriculture is one of the sectors that benefited from it (Samah et al., 2009). The agriculture sector is expected to benefit more from mobile phone in the developing countries as it saves money, time and

\footnotetext{
Department of Distance Education, UAS, GKVK Bangalore, Karnataka, India,

Author for correspondence: narayana.bks@gmail.com
} 
offers accurate advantage for farmers. This can be used to alert villagers about operational activities, disease outbreaks and other important agricultural information. Further, many farmers suffer from lack of up-to-date, and accurate market price information because of their remote location and they are not aware where and how to get trustworthy information. The mobile phone based agricultural information services like IFFCO Kisan Sanchar Limited (IKSL) and Reuters Market Light (RML), launched in some states in 2007 and 2008 are now swiftly becoming popular. These services, through voice-messages provide a variety of agriculture information. Various State Agricultural Universities and ICAR professors have been co-opted in the expert panel of these service providers. The information is provided to farmers in local language, within a specified time and also two-way interaction through customer care centers is available. The farmers who have subscribed to these services have highlighted that they have now become more aware and have also enhanced agricultural earnings. The farmers who are not the subscribers but possess a mobile phone also revealed that the instrument has helped reduce costs and wastages and increased incomes. Indian Farmers Fertilizer Cooperative Limited (IFFCO, together with telecom giant Bharti Airtel and Star Mobitel, with technical support from University of Agricultural Sciences (UAS) Bangalore has promoted IFFCO KISAN SANCHAR LTD (IKSL) as a joint venture. Airtel has extended its network backbone to IKSL and also provides a sustainable income generating business opportunity to Cooperative Societies. In this model, the telecom products of Airtel are made available to farmers and people living in villages through cooperative societies. The same SIM Card which is used for communication is turned into a powerhouse of knowledge for empowering people living in villages through relevant and pertinent information which is being provided by IKSL through Value Added Service (VAS). Through the Green SIM Card (Airtel has over 1.5 million subscribers of this specialized IKSL package), every day, five free voice messages are being delivered to the subscribers. Each such voice message is of one minute duration. The MMS network is used to send the data to groups of farmers, government officials and others working in agricultural sector, looking to type of information they require. Prices of seed, fertilizer and plant protection chemicals, market information, production technologies, weather forecasts etc. can be disseminated to farmers through MMS. India is the potential of mobile in all spheres of development. The mobile phone technology is being used creatively in developing countries to reduce poverty, particularly in remote rural areas of India (Sapna and Navin, 2010). Mobile phones use in rural areas already started as a tool for agricultural transactions. Mobile phones provide a new platform through which rural communities will be able to access government information and services, using text, data, and audio browsing techniques. Hence, the study has been planned with the following objectives:

1. To study the profile of farmers using Mobile Message Service (MMS) network.

2. To know the attitude of farmers and scientists about agricultural technologies disseminated through MMS network.

3. To examine the type of agricultural technologies disseminated through different MMS network.

4. To document the constraints perceived by the farmers and scientists in using MMS network. 


\section{Hypothesis of the study}

Null hypothesis: Variables like age, education, farming experience, occupation, family size and type, annual income, farm size, cropping intensity, irrigation intensity, decision making ability, economic motivation, achievement motivation, innovative proneness, social participation, cosmopoliteness, mass media participation and extension participation had positive and significant relationship with attitude of farmers about agricultural technologies dissemination through MMS network.

Alternate hypothesis: All variables said in null hypothesis had negative and non-significant relationship with attitude of farmers about agricultural technologies dissemination through MMS network.

\section{MATERIALS AND METHODS}

The study was conducted in Doddaballapura of Bangalore Rural District, Karnataka state, India during 2010-11. Purposively Doddaballapura was selected because number of farmers using MMS network is high compared to other locations. The respondents for the study were 40 farmers from Doddaballapura using MMS network and 40 scientists involved in dissemination of technologies through MMS network from Indian Farmers Fertilizers Cooperatives Limited (IFFCO), Kissan Sanchar Limited (IKSL) and Indian Institute of Horticultural Research (IIHR). The respondents for the study were selected by following simple random techniques. The required data were collected from respondents using structured pretested questionnaire and schedules. The data collected were analyzed and tabulated using the statistical tools like percentage, mean and standard deviation, correlation, multiple linear regressions and rank.

\section{RESULTS AND DISCUSSION}

\section{Profile of the farmers using MMS network}

The findings presented in Table 1 indicated that more than half of farmers belonged to middle age group (52.5\%). The probable reason might be that, most of the old age people were not interested to use mobile phones and middle age farmers were enthusiastic to use mobile phones for getting information related to agriculture. Majority of farmers had medium level (52.5\%) to high level $(27.5 \%)$ of education. This might be due to that farmers have easy access to schools and realization of importance of formal education in the present situation. Farmers had medium annual income $(37.5 \%)$ the probable reason, which could be attributed for varied income categories of farmers, might be due to the size of the land holding, asset possession and practicing of subsidiary occupations by the farmers. Farmers had medium irrigation intensity (37.5\%), this may be because of majority of farmers are large-scale farmers having irrigation facility. Majority of farmers had medium material possession $(80 \%)$, the reason could be large-scale farmers possessed more assets compared to small farmers. Farmers had medium decision making ability $(40 \%)$ the reason may be farmers belong to middle age and medium education level. Farmers had medium economic motivation $(47.5 \%)$ the reason might be that farmers are becoming more and more market oriented to get more profit. Farmers had medium innovative proneness $(40 \%)$, may be because of dry land farming they might be interested to try innovations to increase their income. Farmers had medium achievement motivation (42.5\%), the reason is that because of 
poverty farmers developed desire for excellence to overcome poverty. Farmers had medium mass media participation (35\%), the reason may be due to medium level of education as revealed in the study and also maximum interest in current issues and new technology. However, less than half of farmers had high cropping intensity (45\%), this may be because of majority of farmers are large farmers. Less than half of farmers had high cosmopoliteness (42.5\%). Less than half of the farmers had high extension participation (37.5\%), the probable reason for this might be their eagerness in solving their problems with extension workers and also interest in extension activities to gather recent information. Majority of the farmers had farming as major activity (77.5\%), this may be because of non availability of alternative occupations.

Table 1. Profile of the farmers using MMS network

$(n=40)$

\begin{tabular}{|c|c|c|c|}
\hline Variable & Category & Frequency & Per cent \\
\hline \multirow{3}{*}{ Age } & Young $(<35$ years $)$ & 13 & 35.00 \\
\hline & Middle ( $36-50$ years) & 22 & 52.50 \\
\hline & Old ( $>50$ years $)$ & 5 & 12.50 \\
\hline \multirow{3}{*}{ Education } & Low $(<2)$ & 8 & 20.00 \\
\hline & Medium (2-3.49) & 21 & 52.50 \\
\hline & $\operatorname{High}(>3.49)$ & 11 & 27.50 \\
\hline \multirow{3}{*}{ Experience } & Low $(<14.16$ years $)$ & 16 & 40.00 \\
\hline & Medium (14.16-20.68 years) & 11 & 27.50 \\
\hline & $\operatorname{High}(>20.68$ years $)$ & 13 & 32.50 \\
\hline \multirow{2}{*}{ Occupation } & Farming & 31 & 77.50 \\
\hline & Agri business & 9 & 22.50 \\
\hline \multirow{2}{*}{ Family type } & Nuclear & 40 & 100.00 \\
\hline & Joint & 0 & 0.00 \\
\hline \multirow{3}{*}{ Family size } & Small $(<5.33)$ & 11 & 27.50 \\
\hline & Medium(5.33-6.46) & 20 & 50.00 \\
\hline & $\operatorname{Big}(>6.46)$ & 9 & 22.50 \\
\hline \multirow{3}{*}{ Annual income } & Low (Rupees <38773.71) & 14 & 35.00 \\
\hline & $\begin{array}{l}\text { Medium (Rupees 38773.71- Rupees } \\
61076.28 \text { ) }\end{array}$ & 15 & 37.50 \\
\hline & High (Rupees $>61076.28$ ) & 11 & 27.50 \\
\hline Farm size & $\begin{array}{l}\text { Small farmers }(\leq 5 \text { acres }) \\
\text { Large-scale }(>5.0 \text { acres })\end{array}$ & $\begin{array}{c}4 \\
36\end{array}$ & $\begin{array}{l}10.00 \\
90.00\end{array}$ \\
\hline \multirow{3}{*}{ Cropping intensity } & Low $(<155.89)$ & 13 & 32.50 \\
\hline & Medium (155.89-194.86) & 09 & 22.50 \\
\hline & High $(>194.86)$ & 18 & 45.00 \\
\hline \multirow{4}{*}{ Irrigation intensity } & Low $(<55.04)$ & 14 & 35.00 \\
\hline & Medium (55.04-91.20) & 15 & 37.50 \\
\hline & High $(>91.20)$ & 11 & 27.50 \\
\hline & Low $(<18.9)$ & 11 & 27.50 \\
\hline \multirow{2}{*}{ Material possession } & Medium (18.9-38.79) & 20 & 50.00 \\
\hline & $\operatorname{High}(>38.79)$ & 9 & 22.50 \\
\hline \multirow{3}{*}{ Type of the house } & Hut & 0 & 00.00 \\
\hline & Katcha & 17 & 42.50 \\
\hline & Pakka & 23 & 57.50 \\
\hline
\end{tabular}




\begin{tabular}{llcc} 
Decision making & Low $(<16.46)$ & 10 & 25.00 \\
ability & Medium $(16.46-17.13)$ & 16 & 40.00 \\
& High $(>17.13)$ & 14 & 35.00 \\
Economic & Low $(<24.66)$ & 8 & 20.00 \\
motivation & Medium $(24.66-27.43)$ & 19 & 47.50 \\
& High $(>27.43)$ & 13 & 32.50 \\
Innovative & Low $(<22.48)$ & 9 & 22.50 \\
Proneness & Medium $(22.48-24.56)$ & 16 & 40.00 \\
& High $(>24.56)$ & 15 & 37.50 \\
Achievement & Low $(<24.45)$ & 13 & 32.50 \\
motivation & Medium $(24.45-27.04)$ & 17 & 42.50 \\
& High $(>27.04)$ & 10 & 25.00 \\
Social participation & Low $(<11.24)$ & 10 & 25.00 \\
& Medium $(11.24-15.20)$ & 16 & 40.00 \\
Cosmopoliteness & High $(>15.20)$ & 14 & 35.50 \\
& Low $(<10.33)$ & 08 & 20.00 \\
Mass media & Medium $(10.33-14.11)$ & 15 & 37.50 \\
participation & High $(>14.11)$ & 17 & 42.50 \\
& Low $(<13.43)$ & 12 & 30.00 \\
Extension & Medium $(13.43-15.76)$ & 14 & 35.00 \\
participation & High $(>15.76)$ & 14 & 35.00 \\
& Low $(<19.54)$ & 11 & 27.50 \\
& Medium $(19.54-24.30)$ & 14 & 35.00 \\
& High $(>24.30)$ & 15 & 37.50 \\
\hline
\end{tabular}

\section{Attitude of farmers and scientists towards MMS network}

The results observed from Table 2 reveal that both farmers (40\%) and Scientists (45\%) had favourable attitude about MMS network. However, 32.5\% of farmers had most favourable attitude followed by $27.5 \%$ had least favourable attitude towards MMS network. Further, 30 per cent of scientists had least favourable attitude followed by 25 per cent had most favourable attitude towards MMS network. The reason may be the farmers are getting timely and accurate messages from MMS network based on their needs and the scientists are also sending the correct messages to the needy farmers and obtaining feedback from them about efficiency of MMS network.

Table 2. Attitude of farmers and scientists towards MMS network

\begin{tabular}{lcccc}
\hline \multirow{2}{*}{ Category } & \multicolumn{2}{c}{ Farmers $(\mathbf{n}=\mathbf{4 0})$} & \multicolumn{2}{c}{ Scientists $(\mathbf{n}=\mathbf{4 0})$} \\
\cline { 2 - 5 } & Frequency & Per cent & Frequency & Per cent \\
\hline Least favourable & 11 & 27.50 & 12 & 30.00 \\
Favourable & 16 & 40.00 & 18 & 45.00 \\
Most favourable & 13 & 32.50 & 10 & 25.00 \\
Total & 40 & 100.00 & 40 & 100.00 \\
\hline
\end{tabular}

Relationship between personal, socio-economic and psychological and communication characteristics of the farmers and their attitude towards MMS network

The findings of Table 3 reveal that variables such as education, farm size, material possession, economic motivation, innovative proneness, achievement motivation, 
cosmopoliteness, mass media participation and extension participation had positive and significant relationship with attitude of farmers at one per cent level of significance. Whereas, cropping intensity, irrigation intensity, decision making ability and social participation had positive and significant relationship with attitude of farmers at five per cent level of significance. As far as age was concerned, it had negative and significant relationship with attitude of farmers at five per cent level of significance. However, other variables such as farming experience, occupation, family size and annual income were found to have non-significant relationship with attitude of farmers.

Table 3. Relationship between personal, socio-economic and psychological and communication characteristics of the farmers and their attitude towards MMS network $(n=40)$

\begin{tabular}{lc}
\hline Variables & Correlation coefficient (r) \\
\hline Age & $-0.237^{*}$ \\
Education & $0.787^{* *}$ \\
Farming experience & $0.089^{\mathrm{NS}}$ \\
Occupation & $0.048^{\mathrm{NS}}$ \\
Family size & $-0.176^{\mathrm{NS}}$ \\
Annual income & $0.083^{\mathrm{NS}}$ \\
Farm size & $0.715^{* *}$ \\
Material possession & $0.748^{* *}$ \\
Cropping intensity & $0.294^{*}$ \\
Irrigation intensity & $0.307^{*}$ \\
Decision making ability & $0.423^{*}$ \\
Economic motivation & $0.614^{* *}$ \\
Innovative proneness & $0.624^{* *}$ \\
Achievement motivation & $0.509^{* *}$ \\
Social participation & $0.318^{*}$ \\
Cosmopoliteness & $0.621^{* *}$ \\
Mass media participation & $0.568^{* *}$ \\
Extension participation & $0.614^{* *}$ \\
\hline
\end{tabular}

* Significant at the 0.05 level

** Significant at the 0.01 level

NS $=$ Non-Significant

Extent of contribution of personal, socio-economic and psychological characteristics of the farmers and their attitude towards MMS network

The regression test was applied to ascertain the contribution of independent variables on attitude of farmers about MMS network (Table 4). The data showed that $84 \%$ of variation in the attitude of farmers about MMS network was due to the independent variables. The calculated ' $t$ ' value for each of the partial ' $b$ ' value was presented, and among them eight partial ' 'b' values were significant at 0.01 level which related to mass media participation, material possession, economic motivation, innovative proneness, achievement motivation, cosmopoliteness, and farm size. The calculated ' $t$ ' value for each partial ' $b$ ' value are presented, and among them six partial ' $b$ ' values significant at 0.05 level related to age, education, cropping intensity, irrigation intensity, decision making ability and social participation. These fourteen partial ' $b$ ' values had positive relationship. According to ' $t$ ' test criterion, these fourteen variables had contributed most for variation (84\%) in the attitude of farmers towards MMS network. 
Table 4. Extent of contribution of personal, socio-economic and psychological characteristics of the farmers and their attitude towards MMS network

\begin{tabular}{lccc}
\hline Variables & $\begin{array}{c}\text { Regression } \\
\text { coefficient (b) }\end{array}$ & $\begin{array}{c}\text { Standard } \\
\text { error (SEb) }\end{array}$ & $\begin{array}{c}\text { 't' } \\
\text { value }\end{array}$ \\
\hline Age & 1.2787 & 0.640 & $1.998^{*}$ \\
Education & 0.873 & 0.351 & $2.487^{*}$ \\
Farming experience & 0.220 & 0.241 & $0.916^{\mathrm{NS}}$ \\
Occupation & 0.101 & 0.213 & $0.472^{\mathrm{NS}}$ \\
Family size & 0.048 & 0.394 & $0.123^{\mathrm{NS}}$ \\
Annual income & 0.404 & 0.296 & $1.368^{\mathrm{NS}}$ \\
Farm size & 2.511 & 0.590 & $4.256^{* *}$ \\
Material possession & 1.564 & 0.399 & $3.920^{* *}$ \\
Cropping intensity & 1.064 & 0.411 & $2.590^{*}$ \\
Irrigation intensity & 2.117 & 0.720 & $2.940^{*}$ \\
Decision making ability & 1.290 & 0.453 & $2.847^{*}$ \\
Economic motivation & 1.791 & 0.492 & $3.640^{* *}$ \\
Innovative proneness & 1.392 & 0.356 & $3.911^{* *}$ \\
Achievement motivation & 1.714 & 0.409 & $4.201^{* *}$ \\
Social participation & 0.352 & 0.117 & $3.008^{*}$ \\
Cosmopoliteness & 1.721 & 0.418 & $4.118^{* *}$ \\
Mass media participation & 1.821 & 0.394 & $4.621^{* *}$ \\
Extension participation & 1.134 & 0.229 & $4.952^{* *}$ \\
\hline
\end{tabular}

* Significant at the 0.05 level ** Significant at the 0.01 level $\mathrm{NS}=$ Non-Significant $\mathrm{R}^{2}=0.840, \quad \mathrm{~F}=12.047^{*}$

\section{Type of agricultural technologies disseminated through MMS network}

The results in Table 5 indicate the type of technologies disseminated through MMS Network. The technologies are sub divided in to four categories.

\section{a) Agricultural technologies}

The results in Table 5 show that technologies like crop production (50\%), crop management (52.5\%) and marketing (80\%) were the most relevant technologies disseminated through MMS Network. Whereas technologies like input management (55\%), crop protection (50\%), soil and water management (65\%) and harvest and post-harvest $(70 \%)$ were relevant technologies disseminated through MMS Network. The reason may be now a days in agriculture marketing of produce is very important. However, the other aspects like crop production and crop management etc. are also equally important. The results were in consonance with the results of studies conducted by Salleh et al. (2009) and Basavaraj Kattimani (2010).

\section{b) Horticultural technologies}

The results in Table 5 reveal that technologies like tissue culture technique $(55 \%)$, floriculture $(50 \%)$ and food processing $(42.5 \%)$ were the most relevant technologies 
disseminated through MMS Network. Whereas technologies like nursery preparation $(57.5 \%)$, ornamental gardening $(62.5 \%)$, essential oil production $(52.5 \%)$, cold storage $(47.5 \%)$ and preservation $(57.5 \%)$ were relevant technologies disseminated through MMS Network. The reason may be because of advanced technologies in recent years like tissue culture to protect germ plasm for later use. Further, food processing technology is to increase the shelf life and get better price for the produce in the market. Other technologies like nursery preparation, gardening, essential oil production, cold storage and preservation are also important technologies disseminated through MMS network.

\section{c) Veterinary technologies}

The results in Table 5 indicate that technologies like dairy (70\%), poultry $(52.5 \%)$ and sheep and goat $(52.5 \%)$ were the most relevant technologies disseminated through MMS Network. Whereas technologies like piggery (30\%), rabbit (40\%) and fishery $(20 \%)$ were non relevant technologies disseminated through MMS Network. The reason may be in the study area most of the farmers had taken dairy, poultry, sheep and goat rearing as subsidiary activities.

\section{d) Other agriculture related technologies}

The results in Table 5 reveal that technology like weather information $(77.5 \%)$ was the most relevant technology disseminated through MMS Network. Whereas government schemes and programmes (55\%) disseminated were relevant technologies through MMS Network. Due to change in vagaries of monsoon, the information about weather is more relevant. Further, government schemes and programmes are helpful in improving livelihood of farmers. The results were in consonance with the results of studies conducted by Parab et al. (2009). 
Table 5. Type of agricultural technologies disseminated through MMS network

$(n=40)$

\begin{tabular}{|c|c|c|c|c|c|c|c|}
\hline \multirow{3}{*}{$\begin{array}{l}\text { SL } \\
\text { No }\end{array}$} & \multirow{3}{*}{ Technologies } & \multicolumn{6}{|c|}{ Relevancy } \\
\hline & & \multicolumn{2}{|c|}{$\begin{array}{l}\text { Most relevant } \\
\end{array}$} & \multicolumn{2}{|c|}{ Relevant } & \multicolumn{2}{|c|}{ Not relevant } \\
\hline & & Frequency & Per cent & Frequency & Per cent & Frequency & Per cent \\
\hline \multirow[t]{8}{*}{ 1). } & Agricultural Technologies & & & & & & \\
\hline & 1.Input management & 11 & 27.50 & 22 & 55.00 & 7 & 17.50 \\
\hline & 2.Crop production & 20 & 50.00 & 17 & 42.50 & 3 & 7.50 \\
\hline & 3.Crop protection & 18 & 45.00 & 20 & 50.00 & 2 & 5.00 \\
\hline & 4.Soil and water management & 12 & 30.00 & 26 & 65.00 & 2 & 5.00 \\
\hline & 5.Crop management & 21 & 52.50 & 16 & 40.00 & 3 & 7.50 \\
\hline & 6. Harvest and Post harvest & 11 & 27.50 & 28 & 70.00 & 1 & 2.50 \\
\hline & 7.Marketing & 32 & 80.00 & 8 & 20.00 & 0 & 0.00 \\
\hline \multirow[t]{10}{*}{ 2). } & Horticultural Technologies & & & & & & \\
\hline & 1.Nursery preparation & 15 & 37.50 & 23 & 57.50 & 2 & 5.00 \\
\hline & 2.Tissue culture technique & 22 & 55.00 & 17 & 42.50 & 0 & 0.00 \\
\hline & 3.Floriculture & 20 & 50.00 & 19 & 47.50 & 1 & 2.50 \\
\hline & 4.Ornamental gardening & 15 & 37.50 & 25 & 62.50 & 0 & 0.00 \\
\hline & 5.Essential oil production & 15 & 37.50 & 21 & 52.50 & 4 & 10.00 \\
\hline & 6.Cold storage & 17 & 42.50 & 19 & 47.50 & 4 & 10.00 \\
\hline & 7.Preservation & 10 & 25.00 & 23 & 57.50 & 7 & 17.50 \\
\hline & 8.Food processing & 17 & 42.50 & 15 & 37.50 & 8 & 20.00 \\
\hline & Any other(Specify) & 0 & 0.00 & 0 & 0.00 & 0 & 0.00 \\
\hline \multirow[t]{8}{*}{ 3). } & Veterinary Technology & & & & & & \\
\hline & 1.Dairy & 28 & 70.00 & 3 & 7.50 & 9 & 22.50 \\
\hline & 2.Poultry & 21 & 52.50 & 6 & 15.00 & 13 & 32.50 \\
\hline & 3.Sheep and Goat & 21 & 52.50 & 6 & 15.00 & 13 & 32.50 \\
\hline & 4.Piggery & 10 & 25.00 & 18 & 45.00 & 12 & 30.00 \\
\hline & 5.Rabbit & 1 & 2.50 & 23 & 57.50 & 16 & 40.00 \\
\hline & 6.Fishery & 4 & 10.00 & 28 & 70.00 & 8 & 20.00 \\
\hline & 7.Any other(Specify) & 0 & 0.00 & 0 & 0.00 & 0 & 0.00 \\
\hline \multirow[t]{3}{*}{ 4). } & Other Agriculture related Technologies & & & & & & \\
\hline & 1.Government Schemes and Programmes & 1 & 2.50 & 22 & 55.00 & 17 & 42.50 \\
\hline & 2.Weather information & 31 & 77.50 & 9 & 22.50 & 0 & 0.00 \\
\hline
\end{tabular}




\section{Constraints faced by farmers to use MMS network}

The results in Table 6 show that among all the constraints faced by farmers to use MMS network, difficulty in clarification if any doubt arises (Rank I), lack of practical exposure (Rank II), lack of locally relevant information (Rank III), were the major constraints faced by farmers to use MMS network. The reason may be because mobile messages reaching farmers might have doubts, sometimes very difficult to understand, there is no practical experience of technologies and also sometimes the information disseminated through them were not relevant to the situation. This finding is confirmative with the findings reported by Molony (2008) and Wole (2009).

Table 6. Constraints faced by farmers to use MMS network

\begin{tabular}{lccc} 
& & $(\mathbf{n}=\mathbf{4 0})$ \\
\hline Constraints & Score & Per cent & Rank \\
\hline Difficulty in clarification if any doubt arises & 101 & 84.16 & I \\
Lack of practical exposure & 99 & 82.50 & II \\
Lack of locally relevant information & 97 & 80.83 & III \\
Network availability & 70 & 58.33 & IV \\
Cost involvement is more & 64 & 53.33 & V \\
Human element is missing & 63 & 52.50 & VI \\
Electricity problems & 62 & 51.66 & VII \\
Health problems & 57 & 47.50 & VIII \\
Fear to adopt technology & 54 & 45.00 & IX \\
\hline
\end{tabular}

Constraints noticed by scientists while implementing MMS network

The findings in Table 7 show that among all the constraints noticed by scientists while implementing MMS network, lack of practical exposure (Rank I), lack of locally relevant information (Rank II), and difficulty in clarification if any doubt arises (Rank III), were the major constraints. The reason may be that scientists think there is a need for practical exposure of farmers, sometimes farmers clarify their doubts but not all the times and also there is a need for taking feedback from the farmers for improving the system. This finding is confirmative with the findings of Molony (2008).

Table 7. Constraints noticed by scientists while implementing MMS network

\begin{tabular}{lccc} 
& & & $(\mathbf{n}=\mathbf{4 0})$ \\
\hline Constraints & Score & Per cent & Rank \\
\hline Lack of practical exposure & 84 & 70.00 & I \\
Lack of locally relevant information & 83 & 69.16 & II \\
Clarification is difficult if any doubt arises & 82 & 68.33 & III \\
Network availability & 80 & 66.66 & IV \\
Fear to adopt technology & 63 & 52.50 & V \\
Human element is missing & 62 & 51.66 & VI \\
Cost involvement is more & 60 & 50.00 & VII \\
Health problems & 59 & 49.16 & VIII \\
Electricity problems & 54 & 45.00 & IX \\
\hline
\end{tabular}




\section{CONCLUSIONS}

The concept of MMS network is a new approach in transfer of technology. Therefore, the implementing agencies need to keep this in view for dissemination of technologies through MMS network. Majority of the large-scale farmers are using MMS network. Hence, there is a need for extension activities to motivate small farmers for using MMS network. The implementing agencies need to provide locally relevant information to the farmers.

As perceived by farmers in MMS network there is lack of practical exposure and clarification is difficult if doubts arise. Hence, there is a need to find new mechanism to solve this problem.

\section{ACKNOWLEDGEMENT}

I express my deepest sense of gratitude to all those who directly and indirectly helped me in this endeavour. I deem it a great privilege to express my esteemed and profound sense of gratitude to my guide for his guidance and timely efforts, which helped me to do this quality work in the stipulated time period itself. I extend my sincere thanks Postgraduate Institute of Agriculture, University of Peradeniya, Sri Lanka.

\section{REFERENCES}

Basavaraj Kattimani, F. (2010). Agro info beeps in to farmers' cell phones. The Times of India (Daily) dated $27^{\text {th }}$ September, Bangalore, P: 7.

Molony, T. (2008). Running out of credit: The limitations of mobile telephony in a Tanzanian agricultural marketing system. J. Modern African Studies, 46(4), 637-658.

Parab, R.L., Sawant, P.A. and Sananse, S.L. (2009). Mobile phone messages using behaviour and adoption of various technologies by the beneficiary farmers. Financing Agriculture, $41(6), 20-27$.

Salleh Md., Musa Abu Hassan and Jeffrey Lawrence D' Silva. (2009). Agro-based Industry, mobile phone and youth: A recipe for success, European J. Scientific Research, 36(1), 41 48.

Samah, B.A., Shaffril H.A.M., Hassan M.D.S., Hassan M.A. and Ismail N. (2009). Contribution of information and communication technology in increasing agro-based entrepreneurs productivity in Malaysia. J. Agric. Soc. Sci., 5(3), 93-97.

Sapna, A.N. and Navin, N. (2010). ICTs and agricultural supply chains: Opportunities and strategies for successful implementation. Information Technologies in Developing Countries, 20(1), 24-28.

Wole, M.O. (2009). Analyzing Socio-Demographic differences in access and use of ICTs in Nigeria using capability approach Issues in Informing Science and Information Technology, $6,479-496$. 